\title{
СПЕЦИФІКА ЗАЧИНУ НАРОДНОЇ СОЦІАЛЬНО-ПОБУТОВОЇ КАЗКИ
}

Для того, щоб виявити особливості національного світобачення, здійснити комплексний аналіз мовного втілення жанрової специфіки різнотипних народних казок, з'ясувати спільне й відмінне в мові цих творів усної народної словесності, треба приділяти належну увагу мовним особливостям казок різного типу. У статті ми звертаємо увагу на мовну специфіку зачину соціально-побутової казки. Фантастична складова, характерна для більшості казок, заступається в аналізованих творах побутовим, иілком реалістичним елементом, характерним для життя різних верств суспільства. Це певним чином позначається й на інічіальних формулах, що часто через типізацію констатують у казках соціально-побутового типу конкретні явища суспільного життя.

Ключові слова: сочіально-побутова казка, мова фольклору, зачин, інічіальні формули, хронологічні ініціальні формули, топограбічні ініціальні формули, типізація, реалістичність.

\section{Serdeha R. L. Specificity of the Beginning of the Folk Social and House-} hold Tale. Ukrainian scientists were interested mainly in the lingual features of the folk fairy tale. In order to reveal the peculiarities of the national outlook, to carry out a comprehensive analysis of the lingual embodiment of the genre specificity of different types of folk tales, to find out the common and distinct in the language of the folk literature, due attention should be given to other tales, including social and household ones. The urgency of our work is precisely due to this need. Folk tales usually have a kind of short exposition that tells the time of the action or the place where the events take place. Exposure is formed using traditional established formulas and reports the time or place of action. In the article we pay attention to the lingual specificity of the beginning of the social and household tale, we find out the peculiarities of the initial formulae contained there. Initial formulae are generally divided into two large groups. The first group includes chronological formulae or time formulae. They outline the time of the fairy tale events. The second group includes topographic or place formulae. They point to the events described in the tale. Most fairy tales are characterized by a supernatural, charming component. In social-household tales, it is replaced by the everyday ordinary element of life of different segments of society. This element is also reflected in the initial formulae of the social-household tale. In social-fairy tales, such formulae state specific phenomena of social life. Continuing the folk-epic tradition, the social-household fairy tale has incorporated elements of other varieties - animal and heroic epic. Therefore, the beginning of the analyzed tales is much more realistic than the initial formulae of other similar works of oral folk literature 
(heroic-fantasy tales, animal tales). However, it is not completely devoid of traditional elements.

Key words: social and household tale, language of folklore, beginning of a fairy tale, initial formula, chronological initial formulas, topographic initial formula, typification, realism.

\section{Вступ}

Мова фольклору - це специфічна сфера відбиття дійсності, вона виступає своєрідною, національною за своєю суттю і природою, картиною світу. Сьогодні ні в кого з дослідників не викликає сумніву думка про те, що ментальність народу відбивається насамперед у його мові. Мова ж фольклору творить особливу реальність, виражену за допомогою мовних засобів, наявних у текстах традиційної народної творчості, і виступає водночас як засобом збереження, так і засобом передачі духовної спадщини певного народу, бо вона втілює в собі ціннісні домінанти, властиві культурі того або того народу. Українська народна казка теж відбиває основи національного світобачення.

Актуальність дослідження. Українські вчені цікавилися переважно мовними особливостями народної чарівної казки, але для того, щоб виявити особливості національного світобачення, здійснити комплексний аналіз мовного втілення жанрової специфіки різнотипних народних казок, з'ясувати спільне й відмінне у мові цих творів усної народної словесності, треба приділяти належну увагу й іншим казкам, зокрема й соціально-побутовим. Цією потребою якраз і зумовлена актуальність нашої роботи.

Мета статті полягає у з'ясуванні мовної специфіки зачину соціально-побутової казки.

Завдання відповідають поставленій меті, тому вони полягають у комплексному аналізі особливостей ініціальних формул, наявних у мові соціально-побутової казки.

Ступінь дослідженості питання. Особливості ініціальних формул і загалом мова українських народних соціально-побутових казок сьогодні вивчені недостатньо. Так, наприклад, специфіку зачину, ініціальні формули, наявні в текстах казок, переважно чарівних, досліджували Н. Рошияну (Рошияну, 1974), Л. Дунаєвська та О. Таланчук (Дунаєвська, Таланчук, 1983) та ін., а мовні особливості соціально-побутових казок практично не досліджувалися. 


\section{Методи та методики дослідження}

Для з'ясування специфіки зачину соціально-побутової казки використано такі загальнонаукові методи емпіричного дослідження, як спостереження та порівняння. Матеріалом дослідження слугували ініціальні формули, які отримано способом суцільного добору зі збірки «Соціально-побутова казка» (Соціально-побутова казка, 1987).

\section{Результати та дискусії}

В. Гнатюк виділяє соціально-побутові казки в окрему групу прозових творів. Це, на його думку, не казки, а народні оповідання. Такі твори він називає «новелями» (Гнатюк, 1981:171). Вони різноманітні за тематикою і зображують життя різних верств населення (селян, міщан, купців, ремісників, урядників, духовних осіб, вояків, панів і царів). У таких творах наявні також представники різних націй, 3 якими контактує або контактував український народ, - білоруси, волохи (молдавани, румуни), жиди (євреї), литвини (литовці), мадяри (угорці), москалі (росіяни), німці, ляхи (поляки), серби, словаки, татари, цигани. Проте всі казки, зазначає В. Гнатюк, «пересипані фантастичним елементом і коли 6 його вилучено з них, вони перестали би бути казками» (Гнатюк, 1981 : 172). Найважливішою відмінною від казок рисою новел $є$ їхня реальність. «Усі вони зачерпнені з реального побуту і основані на нім у цілості. Коли часом попадеться якийсь фантастичний епізод у новелю, то він напевно дістався туди 3 казки і може бути усунений з неї без страти для цілості» (Гнатюк, 1981 : 174). Зачини соціально-побутових казок, справді, позначені реалістичністю й часто вказують на представників різних соціальних верств, які виступають головними героями у творі: Жив-був один пан (казка «За потрійну плату»), Був у селі пан («Як пан гавкав на старого пня»), Жив багатий-пребагатий дідич (казка «Це не може бути»), Був такий пан ще за кріпацтва іжив одиноко, нежонатий, значить, а скупий такий, що не доведи господи! («Пан та прикажчик»), Раз пан їхав у базар з кучером (казка «Запряжений пан»), Весняного дня король Матяш вивів своїх вельмож на поле, щоб бачили, як селяни сіють кукурудзу і садять картоплю (казка «Як селянин доїв цапів»), Захворів десь якийсь-то иар та й наказує усім панам, усім мужикам, усім міманам, щзоб заходились його розважать та брехні казать, та такої, щ,об у ній і словечка правди не було («Брехня»), Був собі рибалка (казка «Як 
чорт оддячив чоловікові (Жінка не вірний товариш)»), В одній слободі жив піп (казка «Попівський наймит»), Жив собі в одному місті багатий купець («І туди гаряче, і сюди боляче...»), Жив собі на світі один різник (казка «Дванадцять апостолів»), Жив піп $і$ коло його селянин («Як селянин попа медом частував»), Був такий піп, щзо не знав, коли свято і неділя) (казка «Нетямущий піп»), Жив собі у якомусь селі піn, та такий бідници, такий бідний! (казка «Піп-ворожка»), Жив один чоловік по-сусідському з попом («Казка про попівське залицяння»), Жив собі якось один хлібороб («Як миші плуга з'їли»), В одного пана був наймит Іван (казка «Як святі сметану їли»), Був у царя наймит, інічого він там не робив, тільки чоботи шив - шевцем був («Як розживалась царська дочка за шевцем»), Давним-давно жив собі бідний наймит Іван (казка «Бідний Іван і попадя»), Жив на світі бідний чоловік, який мав у хаті лише купу дітей і стару-престару матір («Як попові захотілося золота»), Жив собі один бідний чоловік («Як циган був адвокатом»), Був собі заможний дядько («Ненаситний піп»).

Зачини соціально-побутових казок можуть містити вказівку на етнічну приналежність героя: Один цісар у біді завжди радився з гуиулом, що має робити (казка «Як владика пас гуцулових свиней»), Жив гуиул Дументій («Про льоху-козу»); Жив собі один ицган («Як циган сповідався»), Якось один господар пішов наймати цигана до молотьби («Як циган молотив»). Можуть у зачині бути й відомості про родинні стосунки героїв, їхній сімейний стан: Жили собі в одній слободі брат і сестра; брат був дурник, звали його Іван, сестру звали Хвеською (казка «Дурний Іван та Хвеська - його сестра»), Був собі чоловік та жінка («Явдоха-святоха»), Десь в одному селі жили собі чоловік та жінка (казка «Мудра дівчина»), Один господар мав дуже впертужінку («Про вперту жінку»), У однієї жінки був чоловік, такий собі вахлакуватий та неповороткий, та ще і не мав усіх дома («Живий мрець»); В одному селі жив собі жонатий чоловік («Як дурень розбагатів»), Жив собі одного разу нежонатий парубок («Як чоловік кішку вчив працювати»), Був собі батько, а в нього один син («Батько та син»), Мав чоловік сина («Крадений віл»), У одного чоловіка був син дурень («Про дурня»), Один чоловік мав аж дванадиятеро дітей («Дивакуватий Панас»); В одного чоловіка були три сини: два розумних, а третій дурний («Про трьох братів»), Було два брати - один мав троє коней, а другий - одного («Про хитрого брата»), Жили колись-то два брати: 
один багатий, а другий такий бідний, щзо й не сказати («Про правду і кривду»).

Ініціальні формули, наявні в зачині, загалом поділяють на дві великі групи (Лановик, 2006: 445). Перша група - хронологічні формули, або ж формули часу. Вони окреслюють часову ознаку подій, описуваних у казці. Це, наприклад, такі сталі початкові елементи, як Було ие давним-давно... Було ие давним-давно, коли ще люди ходили на панщину («Про великого грішника»), Колись... Колись, як була кріпаччина, в одного пана служив чоловік («Кріпак і чорт»), Колисв давно... Колись давно їхав я до торгу продавати телицю («Про телицю та пана»), Колись-то, кажуть, за давнвої давнини... Колись-то, кажуть, за давньої давнини, старих людей, нікчемних до роботи, недобрі діти вивозили на лубку у провалля («Син батька на лубку вивозить»), Одного разу, ще в давні часи... Одного разу, ще в давні часи, жив собі багатий - пристрасний коняр («Заморське яйце»), Це було тоді, коли... Це було тоді, коли в солдатах служили по 25 років («Як солдат царя обдурив»). До цієї групи зараховують також зачини з ініціальними формулами, що містять компоненти був, був собі, жив, жив-був, жили собі, жили-були, жило три брати та ін.: Був... Був у поміщика бугай такий, що він ні за що не міг продать його («Про те, як дяк з попом бугая вкрали»), Був у селі... Був у селі пан («Як пан гавкав на старого пня»), Був собі чоловік... Був собі чоловік, і все його жінка слабувала, а вона любилася з попом, а свого чоловіка не любила: все казала, щьо все слаба («Хвора» жінка і піп»), Був собі чоловік, ну, в його хліба не стало, а жнива були, сухо було так, що змолоть ніде було; ну, і пойхав він до другого млина, до такого, що хоч і сухо буває, ну, він не стає («Хитрий мужик»), Був собі один чоловік... Був собі один чоловік, Хома, а в нього жінка - хороча-прехороша, а до тієї жінки та ходив полюбовник («Дурному ні в людях, ні дома»), Були собі два брати... Були собі два брати: один був дуже багатий, другий - бідний («Два брати»), Було на світі двоє друзів... Було на світі двоє друзів, щьо тільки брехнею й жили («Брехач і підбрехач»), Жив-був... Живбув один пан (казка «За потрійну плату»), Жив... Жив багатий-пребагатий дідич (казка «Це не може бути»), Жило три брати... Жило три брати: всі три Кіндрати («Чи правда це?»). Вищезазначені сталі конструкції вказують певною мірою на час, на те, що подія відбувалася в минулому. 
Переважна більшість таких ініціальних часових формул не містить вказівки на конкретний час. Він видається невизначеним і завжди переноситься переважно в далеке минуле: Одного разу, ще в давні часи, жив собі багатий - пристрасний коняр; Колись давно їхав я до торгу продавати телиию, Колись-то, кажуть, за давньой давнини, старих людей, нікчемних до роботи, недобрі діти вивозили на лубку у провалля тощо. Проте соціально-побутові казки, з огляду на реалістичність зображуваного в них, бо надзвичайне, як у героїкофантастичних казках, у них теж може бути, але воно має переважно комічне забарвлення і подається крізь призму звичайного буденного життя, містять і конкретніші часові елементи, характерні для побуту різних верств населення, переважно селян, (згадується день тижня, свято, під час якого відбувалася дія, пора року, окреслюється реальна історична доба, як-от: У великодню суботу ішов із міста бідний хлопець («Багач та хлопець із села Розумовичів»), Діялося це взимку («Поділена нагорода»), Це було тодi, коли в солдатах служили по 25 років, Було це давним-давно, коли ще люди ходили на панщину, Колись, як була кріпаччина, в одного пана служив чоловік, Був такий пан ще за кріпацтва і нв одиноко, нежонатий, значить, а скупий такий, щзо не доведи господи!.

Друга група - топографічні, або ж формули місця, які вказують на те, де відбувались описувані події: В одному селі люди перестали ходити до иеркви («Двом помогло»), Десь на Десні у десятому иарстві, у іншому государстві був собі чоловік та жінка, та в них не було дітей («Семиліточка»), За сімома горами, за сімома ріками жив собі один багатий чоловік («На світі є і дурніші за мою жінку...»). Місце дії видається не окресленим (В одному селі...) або й зовсім фантастичним (За сімома горами, за сімома ріками...). Однак у соціально-побутових казках є зачини і з виразно окресленим місцем дії, що вказують на цілком реальний географічний об’єкт. Наприклад, Жили в Новому Давидкові, на Мукачівщині, чоловік з жінкою («Про чоловіка, що проміняв воли на калитку»). І досі $є$ на Україні село Нове Давидкове, розташоване в Мукачівському районі Закарпатської області.

Деякі ініціальні формули містять обидві ознаки - часу та простору: У старі часи в одному селі жили три брати-бідняки («Багач без носа»), Жив-був в одному селі хлопець Климка («Казка про Климку»), Якось один піп трохи підпив у війта на хрестинах і почав 
вихвалятися («Як гуцул наймався у попа»), Весняного дня король Матяш вивів своїх вельмож на поле, щоб бачили, як селяни сіють кукурудзу і садять картоплю. У зачині може бути розлоге повідомлення, що містить указівку на час, місце дії і дійову особу. Наприклад, Було, де не було, за високими горами, за широкими лісами, за глибокими морями, отак десь у горах, в невеличкому селі жив собі один чоловік, на ймення Максим («Казка про одного чоловіка, який давав на божеє вола, щоб бог дав йому сторицею»). Щоправда, час невизначений та й місце дії окреслене майже так, як у героїко-фантастичних казках (було, де не було, за високими горами, за широкими лісами, за глибокими морями, отак десь у горах, в невеличкому селі), що, власне, й створює казковий фон.

Інколи ініціальні формули соціально-побутової казки зовсім позбавлені реалістичного наповнення, мають невизначене місце дії, час, загалом невизначений часопростір, що ніби підкреслює несправжність описуваного в ній, як-от Жив де не жив циган («Про циганське мантило»), Ні в якім городі жив Кирик-мужичок («Кирик»), Жив де не жив один бідний чоловік, якого звали Маньком («Як бідний Манько святив паску»). Такі формули, очевидно, перенесені в тканину цих епічних творів, які виникли значно пізніше за інші казкові оповіді, з героїко-фантастичного й тваринного епосу.

Наявні в соціально-побутових казках і зачини з гумористичним забарвленням. Наприклад, Слухай мене, Горішнього, та й Мелика грішного. То оті два, щьо рубали дрова, $m$ й ті три, щзо ганяли вітри, та й ті чотири, щзо горох молотили, та й ті п'ять, щзо у вівсяній соломі сплять, та й ті шість, що держать кобилу за хвіст, $m$ а й ті сім, що у них була церква з книша, пирогами побита, а ковбасні двері яйщем замкнені («Як слуга відучував попа ходити попа до молодиці»). Інколи такі казки починаються примовкою, яка не пов’язана з подальшою розповіддю: Було не було, в сімдесят сьомій державі, за скляною горою, за Черленим морем. Так би держалися вороги на силах, як пісок на вилах. Жив собі один бідний чоловік («Як бідняк грошей від Бога випросив»). Цю казочку - аби не збрехати і правду не сказати - мені сорока принесла на довгому хвості. А та сорока чула від іншої сороки, що була в гуцульському селі і знала там одного мудрого чоловіка («Хочеш до раю - кукурікай!»). 
$€$ ряд соціально-побутових казок, у яких відсутні традиційні форми зачину Жили-були, Жив собі, В одного чоловіка були три сини, Десь в одному селі жили та ін. На початку в таких творах маємо вказівку на буденні, цілком властиві для реального життя, події: $3 a-$ думав один парубок жениться («Кругленьке словечко»), Іила одного разу дорогою стара баба («Мудра баба»), Бідний наймит Олекса служив у попа («Про попа, наймита і пса Муцика»), Піп з дяком хоронили одного чоловіка («Як піп з дяком хотіли вкрасти баранця, та чому їм не вдалось»), Пінли раз три брати у хащу по дрова («Казка без правди»), Іде чоловік з сокирою, а бариня сидить під вікном («Як мужик пана дурив»), Служив хлопець у поміщика, пас табун коней («Хлопець та мужик»), Ішов чоловік шляхом, а над шляхом росла якась деревина («Циган та чоловік»), Один чоловік та хотів вивірити, чи можна жінкам правду казати («Чи можна жінкам правду казати») та ін.

У зачині часто відбувається і знайомство з головним героєм казки, типізованим персонажем без імені: Був собі заможний дядько, Був собі один газда, Було собі два брати..., Жив собі піп та ін. Проте можуть бути ознаки й певної індивідуалізації героїв, що створюється введенням в оповідь загалом і в ініціальну формулу зокрема імені: Жив гуиул Дументій, Жив-був в одному селі хлопець Климка. Щоправда, в деяких випадках ім'я теж може служити засобом швидше узагальнення, ніж індивідуалізації. Наприклад, таке узагальнення маємо в імені Іван, що в соціально-побутових казках ототожнюється з поняттям «дурна, недалека людина» (Жили собі в одній слободі брат і сестра; брат був дурник, звали його Іван, сестру звали Хвеською («Дурний Іван та Хвеська - його сестра») або «хитра, розумна людина, яка прикидається дурною, тільки тимчасово видає себе за таку» (Був собі Іван, звали його дурень («Як Іван волив панів на тамтой світ»)). Завдяки імені може обігруватися комізм ситуації: $B$ одному селі жив чоловік, щзо називався Пригодою («Про дурних багачок»).

Загалом дійовими особами в соціально-побутових казках, на відміну від чарівних, де можуть бути фантастичні істоти, виступають реальні люди (представники різних соціальних верств населення, особи, що перебувають у тих чи тих родинних стосунках). Однак інколи в таких казках натрапляємо на персоніфіковані образи Правди $\boldsymbol{i}$ Кривди (Неправди). Як, наприклад, у зачині казки «Правда та 
неправда», де ці істоти зустрічаються одна з одною: Раз Правда зустрілась із Неправдою. Ці поняття безпосередньо пов’язані із соціальною дійсністю, тому казки подібного типу цілком можна вважати окремим тематичним типом соціально-побутових казок.

Ініціальні формули в зачині можуть бути виражені розгорнутими і лаконічними конструкціями. Розгорнуті конструкції можуть мати вигляд складнопідрядного речення - У далекому изарстві, куди звір не забіжить і пташка не долетить, жив один ияар, що мав дванадияяь дочок» («Тодорко й найстарша царівна»), безсполучникового Жили собі в одній слободі брат і сестра; брат був дурник, звали його Іван, сестру звали Хвеською, сполучатися різними типами синтаксичного зв'язку - В іншому иарстві, у козацькому гетьманстві, у такому селі, як Пикарі, і там жило два брати: один убогиц̆, другий багатий («Убогий та багатий»), простого речення, ускладненого однорідними членами речення - За сімома горами, за сімома ріками жив собі один багатий чоловік («На світі $є$ і дурніші за мою жінку...»). Лаконічні мають форму простого речення, що може складатися тільки 3 підмета та простого дієслівного присудка ускладненого часткою собі: Жив собі піn («Аби гроші - гріха не буде»), Був собі рибалка (казка «Як чорт оддячив чоловікові (Жінка не вірний товариш»)), містити, крім головних членів речення, один другорядний: Мав чоловік сина («Крадений віл») (присудок, підмет і додаток), Жив гуиул Дументій («Про льоху-козу») (присудок, підмет і прикладкові означення); Жив собі один изиган («Як циган сповідався») (простий присудок, ускладнений часткою собі, та підмет, що становить поєднання кількісного числівника з іменником). Можуть бути прості поширені синтаксичні конструкції з кількома другорядними членами речення - B одній слободі жив піп (казка «Попівський наймит»). В ініціальній формулі може бути відразу кілька підметів і один присудок. Наприклад, Був собі чоловік та жінка (казка «Явдоха-святоха»), Був собі чоловік іжін$\kappa a$ («Про того чоловіка, що купив жінці таку куртку, як пані носить»). Загалом дієслово-присудок узгоджується в числі з підметом: якщо підмет стоїть в однині чи множині, то й дієслово теж повинно виступати в цьому ж числі. Проте у вище наведених прикладах дієсловоприсудок був з часткою собі стоїть перед двома підметами. У такому випадку, як правило, орієнтуються на число першого підмета, хоча в цьому контексті вони обидва стоять в однині. 


\section{Висновки}

Отже, продовживши народно-епічну традицію, соціально-побутова казка увібрала елементи інших різновидів - тваринного та героїчного епосу. Анімістичні уявлення трансформуються в антропоморфічні образи (Правди і Кривди та ін.). Надприродний, чарівний елемент заступається побутовим, цілком буденним і звичайним для життя різних верств суспільства. Це певним чином позначається й на ініціальних формулах, що часто через типізацію констатують конкретні явища суспільного життя був такий пан, був такий піп та ін. Кожен персонаж - це тип, представник соціальної верстви, до якої він належить, а зачин соціально-побутової казки може виходи за рамки традиційних усталених формул, що мають виразну казкову форму (жив-був, жили-були) і заступатися синтаксичними конструкціями, що окреслюють буденні, цілком властиві для реального життя, події. Отже, зачин досліджуваних казок набагато реалістичніший за ініціальні формули в інших подібних творах усної народної словесності (чарівних, казках про тварин), хоча й повністю не позбавлений традиційних елементів.

\section{ЛІТЕРАТУРА}

1. Гнатюк В. Народні новелі 1917 (передмова). Записки НТШ / упоряд. Б. Романенчук. Нью Йорк, 1981. Т. 201: Вибрані статті про народну творчість: на 110-річчя народження 1871-1981. С. 171-175. 2. Дунаєвська Л. Ф., Таланчук О. М. Функція типологічних ініціальних і фінальних формул російських та українських чарівнофантастичних казок. Вісник КНУ. Вестник КНУ. Bulletin of the Kiev National University. 1983. Вип. 25. С. 92-98. 3. Лановик М. Б., Лановик 3. Б. Українська усна народна творчість: підручник. 4-те вид., стер. Київ: Знання-Прес, 2006. 591 с. 4. Рошияну Н. Традиционные формулы сказки. Москва: Восточн. лит-ра, 1974. 216 с. 5. Соціальнопобутова казка / упоряд., передм., приміт. О. Бріциної. Київ: Дніпро, 1987. 282 с.

\section{REFERENCES}

1. Hnatiuk, V. (1981). Narodni noveli 1917 (peredmova) [Folk novels 1917 (preface)]. Hnatiuk, V. \& Romanenchuk, B. (Eds.). Zapysky Naukovoho tovarystva imeni Shevchenka - Notes of the Shevchenko Scientific Society (Vol. 201), (pp. 171-175). New York [in Ukrainian]. 2. Dunaievska, L. F., Talanchuk, O. M. (1983). Funktsiia typolohichykh inisialnykh i finalnykh formul rosiiskykh ta ukrainskykh charivno-fantastychykh kazok [Function of typological initial and final formules of Russian and Ukrainian fairy-tale tales]. Visnyk KNU - Bulletin of the Kiev National University, 25, $92-98$ [in Ukrainian]. 3. Lanovyk, M. B., Lanovyk, Z. B. (2006). Ukrainska usna narodna tvorchist [Ukrainian oral folk art]. Kyiv: 
Znannia-Pres [in Ukrainian]. 4. Roshiianu, N. (1974). Traditsionnyie formuly skazki [Traditional fairy tale formulas]. Moskva: Vostochnaia literatura [in Russian]. 5. Britsyna, O. (1987) Sotsialno-pobutova kazka [A social and household tale]. Kyiv : Dnipro [in Ukrainian].

Сердега Руслан Леонідович - кандидат філологічних наук, доцент, доцент кафедри української мови, Харківський національний університет імені В. Н. Каразіна. Майдан Свободи, 4, м. Харків, 61000, Україна.

Tel.: +380966662971

E-mail: ruslan.serdega@ukr.net

https://orcid.org/0000-0001-7064-4547

Serdeha Ruslan Leonidovich - Ph.D in Philology, Associate Professor, Ukrainian Language Department, V. N. Karazin Kharkiv National University. Freedom Sqr., 4, Kharkiv, 61000, Ukraine.

Надійшла до редакції 11 жовтня 2019 року 